\title{
Faktor yang berhubungan dengan stunting pada balita di wilayah kerja Puskesmas Air Bangis kabupaten Pasaman Barat
}

\author{
Yuliza Anggraini ${ }^{1 *}$, Pagdya Haninda Nusantri Rusdi ${ }^{2}$ \\ 1,2Universitas Muhammadiyah Sumatera Barat
}

\section{INFORMASI ARTIKEL:}

\begin{tabular}{l}
\hline Riwayat Artikel: \\
Tanggal diterima: 4 November 2019 \\
Tanggal di revisi: 26 November 2019 \\
Tanggal di Publikasi: 30 Desember 2019 \\
\hline Kata kunci: \\
Sanitasi \\
Pola Asuh \\
Pemanfaatan Posyandu \\
Stunting \\
Balita
\end{tabular}

$\underline{10.32536 / \text { jrki.v3i2.56 }}$

Key word:

Sanitation

Parenting

Utilization of Posyandu

Stunting

A toddler

\section{ABSTRAK}

Latar belakang: Data Riskesdas menunjukkan prevalensi stunting di Indonesia meningkat dari 35,6\% pada tahun 2010 menjadi 37,2\% pada 2013. Provinsi Sumatera Barat menempati urutan ke 17 dari 34 provinsi stunting di Indonesia dengan prevalensi anak balita (usia 24-59 bulan) stunting 36,2\% lebih tinggi daripada prevalensi nasional 35,3\%. Prevalensi stunting di Pasaman Barat adalah 51,54\% dan jumlah anak stunting adalah 23.435. Tujuan penelitian: Diketahui faktor penyebab terjadinya stunting pada balita di wilayah kerja Puskesmas Air Bangis Kabupaten Pasaman Barat. Metode: Jenis penelitian adalah cross-sectional dengan pendekatan kuantitatif. Populasi adalah seluruh balita yang datang ke Posyandu di wilayah kerja Puskesmas Air Bangis. Jumlah sampel adalah 200 balita dipilih secara purposive sampling. Data yang digunakan adalah data primer dengan metode wawancara dan observasi. Instrumen menggunakan lembar checklist. Hasil: Sebagian besar balita berjenis kelamin laki-laki (57,5\%), sebagian besar ibu balita memiliki pendidikan sekolah menengah pertama $(48,5 \%)$ dan bekerja sebagai IRT $(95,5 \%)$ dengan jumlah anak 3-5 orang (67\%), sebagian besar balita memiliki tinggi badan normal (66\%) dengan status gizi baik ((55,5\%). Sebagian besar responden memiliki pola asuh baik balita dengan tinggi badan tidak stunting $(37,5 \%)$, sebagian besar responden yang memanfaatkan posyandu memiliki balita dengan tinggi badan tidak stunting $(36,5 \%)$ namun sebagian besar responden memiliki sanitasi lingkungan dan memiliki balita stunting (23\%). Simpulan: Sebagian besar responden memiliki pola asuh yang baik memiliki balita tidak stunting $37,5 \%$, sebagian besar responden yang memanfaatkan Posyandu memiliki balita tidak stunting yaitu $36,5 \%$ dan sebagian besar responden dengan sanitasi lingkungan yang tidak baik dengan balita stunting $23 \%$.

Background: Riskesdas data shows the prevalence of stunting in Indonesia increased from $35.6 \%$ in 2010 to $37.2 \%$ in 2013. West Sumatra Province ranks 17th out of 34 stunting provinces in Indonesia with the prevalence of children under five (ages 24-59 months) stunting 36.2\% higher than the national prevalence of $35.3 \%$. The prevalence of stunting in West Pasaman is $51.54 \%$ and the number of stunting children is 23,435 . The purpose of this study is to determine the factors causing stunting in children under five in the working area of Air Bangis Health Center, West Pasaman Regency. Method: This type of research is cross-sectional with a quantitative approach. The population is all children under five who come to the posyandu in the working area of the Air Bangis Community Health Center. The number of samples is 200 toddlers selected by purposive sampling. The data used are primary data with interview and observation methods. The instrument uses a checklist sheet. Results: found that most of the toddlers are male (57.5\%), most mothers of toddlers have junior high school education (48.5\%) and work as IRT (95.5\%) with 3-5 children (67\%), most toddlers have normal height (66\%) with good nutritional status ((55.5\%), most respondents have good parenting pattern of toddlers with not stunting height (37.5\%), most respondents who utilizing posyandu to have toddlers with stunting height (36.5\%) but the majority of respondents have environmental sanitation and have stunting toddlers (23\%).

Conclusion: most of the respondents had good parenting, had $37.5 \%$ nonstunting toddlers, most of them used posyandu to have non-stunting toddlers, namely $36.5 \%$, but most of them had poor environmental sanitation with $23 \%$ stunting toddlers. 


\section{Pendahuluan}

Stunting merupakan tinggi badan yang kurang menurut umur (<-2SD), ditandai dengan terlambatnya pertumbuhan anak yang mengakibatkan kegagalan untuk mencapai tinggi badan yang normal sesuai usia anak. Dampak jangka pendek berupa peningkatan mortalitas dan morbiditas sedangkan dampak jangka panjang berupa perawakan yang pendek, penurunan kesehatan reproduksi, penurunan kapasitas belajar,dan peningkatan penyakit tidak menular. Pada akhirnya stunting berdampak pada pendek lintas generasi. Balita lebih beresiko terhadap stunting karena lebih rentan terhadap perubahan. Stunting dapat menyebabkan perkembangan sel otak tidak sempurna Apabila gangguan tersebut terus berlangsung maka akan terjadi penurunan skor tes IQ sebesar 10-13 point sehingga anakanak tersebut akan menjadi beban bagi masyarakat dan pemerintah, karena harus mengeluarkan biaya kesehatan yang tinggi akibat warganya mudah sakit. Data Riskesdas menunjukkan prevalensi stunting di Indonesia meningkat dari 35,6\% pada tahun 2010 menjadi $37,2 \%$ tahun 2013. Prevalensi tersebut menjadikan Indonesia lima besar negara dengan angka stunting tertinggi di dunia.

Provinsi Sumatera Barat menempati urutan ke-17 dari 34 Propinsi stunting di Indonesia dengan prevalensi balita (usia 24-59 bulan) stunting sebesar $36,2 \%$ lebih tinggi dari prevalensi nasional yaitu 35,3\%. Pasaman Barat merupakan urutan kedua Kabupaten/kota di Provinsi Sumatera Barat dengan prevalensi stunting sebesar $51,54 \%$ dengan jumlah balita stunting adalah 23.435 jiwa. Nagari Air Bangis Kabupaten Pasaman Barat merupakan salah satu Nagari di 100 Kabupaten/Kota di Sumatera Barat yang mendapatkan prioritas tahap I penanganan stunting di Indonesia tahun 2018. Prevalensi stuting bisa saja meningkat apabila faktor-faktor risiko penyebab stunting tidak diperhatikan. Peranan keluarga atau pola asuh ibu sangat penting dalam tumbuh kembang anak, hal itu berkaitan dengan sikap dan pengethuan ibu tentang pola gizi yang baik untuk tumbuh kembang anaknya. Sanitasi lingkungan juga berperan

\footnotetext{
* Korespondensi penulis.

Alamat E-mail: yulizaanggraini@gmail.com
}

terhadap kejadian stunting. Kejadian stunting pada baduta di Indonesia tahun 2014 didapatkan bahwa keluarga yang menggunakan sanitasi lingkungan (penggunaan fasilitas buang air besar dan tempat pembuangan akhir kotoran) yang tidak layak memiliki risiko 1,2 kali badutanya untuk stunting. Posyandu mempunyai manfaat terhadap masyarakat antara lain pertumbuhan balita terpantau sehingga tidak menderita kurang gizi/gizi buruk, bayi dan anak balita mendapatkan vitamin A, bayi memperoleh imunisasi lengkap, stimulasi tumbuh kembang balita dengan menggunakan alat permainan edukatif di posyandu, mendeteksi dini tumbuh kembang, memperoleh penyuluhan kesehatan tentang ibu dan anak serta berfungsi untuk membagi pengetahuan dan pengalaman tentang kesehatan ibu dan anak. Penelitian yang dilakukan Maya Adiyanti menyebutkan bahwa baduta yang tidak memanfaatkan posyandu memiliki risiko 1,3 kali lebih tinggi menderita stunting dibandingkan dengan baduta yang memanfaatkan posyandu.

\section{Metode penelitian}

Jenis penelitian yang digunakan dalam penelitian ini adalah cross-sectional dengan pendekatan kuantitatif. Variabel dependen dalam penelitian ini adalah kejadian stunting pada balita usia 24-59 bulan. Variabel independennya adalah karakteristik balita (usia, jenis kelamin, berat badan lahir, panjang lahir, imunisasi dasar) karakteristik ibu balita (usia ibu, tinggi ibu, jumlah pendidikan ibu), variabel pola asuh ibu, variabel sanitasi lingkungan dan variabel pemanfaatan posyandu. Populasi dalam penelitian ini adalah seluruh balita yang datang ke posyandu di wilayah kerja puskesmas Air Bangis Kabupaten Pasaman Barat. Sampel dalam penelitian ini diambil dengan teknik consecutive sampling yang dilakukan di beberapa posyandu. Terpilih 3 posyandu dari 18 posyandu yang ada dengan pertimbangan waktu pelaksanaan posyandu bertepatan dengan waktu penelitian. Sampel dalam penelitian ini berjumlah 200 balita di wilayah kerja Puskesmas Air Bangis.

\section{Hasil dan Pembahasan}

Distribusi responden berdasarkan jenis kelamin balita, panjang lahir balita, pendidikan ibu, jumlah anak, dan pekerjaan ibu 
Tabel 1. Distribusi responden berdasarkan jenis kelamin balita, panjang lahir balita, pendidikan ibu, jumlah anak dan pekerjaan ibu

\begin{tabular}{lcc}
\hline \multicolumn{1}{c}{ Karakteristik } & Frek & $\%$ \\
\hline Jenis kelamin & 115 & \\
$\quad$ Laki-laki & 85 & 42,5 \\
$\quad$ Perempuan & 200 & 100 \\
Jumlah & & \\
Pendidikan ibu & 38 & 19 \\
SD & 97 & 48,5 \\
SMP & 65 & 32,5 \\
SMA & 200 & 100 \\
Jumlah & & \\
Jumlah Anak & 11 & 5,5 \\
2 & 134 & 67 \\
3-5 & 55 & 27,5 \\
$>5$ & 200 & 100 \\
Jumlah & & \\
Pekerjaan & 191 & 95,5 \\
IRT & 9 & 4,5 \\
Bekerja & $\mathbf{2 0 0}$ & $\mathbf{1 0 0}$ \\
Jumlah & &
\end{tabular}

Berdasarkan data dari tabel 1 menunjukkan bahwa sebagian besar responden yaitu $57,5 \%$ berjenis kelamin laki-laki dan sebagian kecil 42,5\% berjenis kelamin perempuan. Sebagian besar 48,5\% ibu memiliki pendidikan SMP dan hanya sebagian kecil yaitu 19\% ibu berpendidikan SD. Selanjutnya sebagian besar responden 67\% memiliki jumlah anak 3-5 orang dan hanya 5,5\% responden memiliki julah anak 2 . Sebagian besar 95,5\% bekerja sebagai ibu rumah tangga dan sebagian kecil yaitu $4,4 \%$ responden yang bekerja.

Tabel 2. Distribusi responden berdasarkan tinggi badan dan status gizi balita

\begin{tabular}{lcc}
\hline \multicolumn{1}{c}{ Variabel } & N & \% \\
\hline $\begin{array}{l}\text { Tinggi Badan } \\
\text { Normal (Tdk } \\
\text { stunting) }\end{array}$ & 132 & 66 \\
$\begin{array}{l}\text { Pendek } \\
\text { (Stunting) }\end{array}$ & 68 & 34 \\
Jumlah & $\mathbf{2 0 0}$ & \\
Status Gizi & & $\mathbf{1 0 0}$ \\
Obesitas & 0 & \\
Gizi Lebih & 1 & 0 \\
Gizi baik & 111 & 0,5 \\
Gizi Kurang & 65 & 55,5 \\
Gizi buruk & 23 & 32,5 \\
Jumlah & $\mathbf{2 0 0}$ & 11,5 \\
\hline
\end{tabular}

Berdasarkan data dari tabel 2 menunjukkan bahwa sebagian besar yaitu $66 \%$ responden memiliki tinggi badan normal (tidak stunting) dan sebagian kecil responden yaitu 34\% memiliki tinggi badan pendek (stunting). Sebagian besar responden yaitu $55,5 \%$ memiliki status gizi baik dan sebagian kecil responden yaitu $11,5 \%$ memiliki gizi buruk.

Tabel 3. Distribusi frekuensi penyebab stunting pada balita usia 24-59 bulan

\begin{tabular}{lcccc}
\hline \multirow{2}{*}{ Faktor } & \multicolumn{2}{c}{ Normal } & \multicolumn{2}{c}{ Stunting } \\
\cline { 2 - 5 } & Frek & $\%$ & Frek & $\%$ \\
\hline Pola asuh ibu & & & & \\
$\quad$ Baik & 73 & 37,5 & 29 & 14,5 \\
$\quad$ Tidak baik & 63 & 31,5 & 35 & 17,5 \\
\hline Pemanfaatan & & & & \\
posyandu & & & & \\
$\quad$ Dimanfaatkan & 73 & 36,5 & 49 & 24,5 \\
$\quad$ Tdk dimanfaatkan & 47 & 23,5 & 31 & 15,5 \\
\hline Sanitasi lingkungan & & & & \\
$\quad$ Baik & 58 & 29 & 22 & 11 \\
$\quad$ Tidak baik & 74 & 37 & 46 & 23 \\
\end{tabular}

Berdasarkan data tabel 3 didapatkan hasil bahwa responden yang memiliki pola asuh yang baik memiliki balita stunting sebanyak 29 orang $(14,5 \%)$ sedangkan responden yang memiliki pola asuh yang tidak baik memiliki balita stunting sebanyak 35 orang (17,5\%). Dari factor pemanfaatan posyandu didapatkan responden yang memanfaatkan posyandu sebagai sarana pelayanan kesehatan yang memiliki balita dengan tinggi badan normal sebanyak 73 orang $(37,5 \%)$ dan memiliki balita stunting sebanyak 49 orang (24,5\%). Sedangkan pada responden yang tidak memanfaatkan posyandu sebagai sarana pelayanan kesehatan memiliki balita dengan tinggi badan normal sebanyak 47 orang $(23,5 \%)$ dan memiliki balita stunting sebanyak 31 orang (15,5\%). Dilihat dari faktor sanitasi lingkungan responden yang sanitasi lingkunganya baik memiliki balita dengan tinggi badan normal 58 orang $(29 \%)$ dan memiliki balita stunting 22 orang (11\%), sedangkan responden dengan sanitasi lingkungan yang tidak baik memiliki balita dengan tinggi badan normal 74 orang (37\%) dan memiliki balita stunting 46 orang (23\%) pada balita baik dari ibu.

Hasil penelitian menujukkan bahwa sebagian besar responden dengan pola asuh yang baik akan memiliki balita dengan tinggi badan yang normal/ tidak stunting (37,5\%).

Teori positive deviance (Zeitlin,1990) menyatakan bahwa berbagai stimulus yang rutin diberikan oleh ibu atau pengasuh terhadap bayi, baik stimulus visual, verbal dan auditif akan dapat menyebabkan stimulasi growth hormone, 
metabolisme energy menjadi normal dan imun respon lebih baik.

Menurut penelitian Rahmayana (2014) bahwa peran keluarga terutama ibu dalam mengasuh anak akan menentukan tumbuh kembang anak. Perilaku ibu dalam menyusui atau memberi makan, cara makan yang sehat, memberi makanan yang bergizi dan mengontrol besar porsi yang dihabiskan akan meningkatkan status gizi anak. Selain itu, anak yang mendapatkan dukungan lebih dari ibu dalam hal pemberian makanan akan berpengaruh positif kepada keadaan status gizi anak tersebut.

Hasil penelitian ini menunjukkan bahwa sebagian besar responden memanfaatkan posyandu sebagai akses pelayanan kesehatan memiliki balita dengan tinggi badan normal/tidak stunting (36,5\%).

Menurut Green dalam Notoatmodjo (2012) mengatakan bahwa perilaku masyarakat berkaitan dengan pelayanan kesehatan dipengaruhi oleh beberapa factor yaitu predisposisi seperti pengetahuan dan sikap masyarakat. Factor pemungkin yaitu akses masyarakat terhadap fasilitas posyandu. Akses terhadap fasilitas dapat mendukung dan memungkinkan terwujudnya perilaku sehat. Factor penguat berupa sarana dan prasarana serta keterampilan kader dalam pemantauan tumbuh kembang anak, sikap tokoh agama dan tokoh masyarakat serta sikap petugas kesehatan. Tingkat partisipasi masyarakat untuk datang dan memanfaatkan posyandu sangat tergantung oleh pergerakan sasaran oleh tokoh masyarakat dan tokoh agama.

Hasil penelitian menunjukkan bahwa responden dengan sanitasi lingkungan yang tidak baik memiliki 2 kali lebih banyak balita stunting (23\%) dibandingkan dengan responden dengan sanitasi lingkungan yang baik dan memiliki balita stunting (11\%).

Menurut Turnip (2008) dalam Adiyanti, (2014), Kebersihan tubuh, makanan dan lingkungan berperan penting dalam memelihara kesehatan akan serta mencegah penyakit-penyakit diare dan infeksi kecacingan. Satu kebiasaan yang bersih seperti mencuci tangan dengan sabun sebelum makan dan setelah buang air besar, telah menjadi fokus kampanye WHO untuk mengurangi timbulnya penyakit-penyakit diare.

Checkley et al (2004) dalam Ardianti, M (2014) menyebutkan bahwa baduta yang memiliki akses sanitasi yang tidak baik memiliki deficit tinggi badan $0,9 \mathrm{~cm}$, dan baduta yang memiliki sumber air yang buruk memiliki tinggi badan $1,0 \mathrm{~cm}$ lebih pendek dibandingkan dengan baduta yang memiliki akses dan sumber air yang baik.

Menurut penelitian Maya Adiyanti (2014), masalah lingkungan dan pemberian makanan yang tidak baik dapat menimbulkan berbagai penyakit pada bayi dan anak-anak diantaranya adalah diare. Diare adalah salah satu penyakit infeksi yang dapat mempengaruhi pertumbuhan secara linier. Penyakit infeksi yang parah dan terjadi berulang dalam jangka waktu yang lama dapat menyebabkan stunting.

\section{Simpulan}

Berdasarkan hasil penelitian dapat disimpulkan bahwa Faktor yang Berhubungan dengan Stunting pada Balita di Wilayah Kerja Puskesmas Air Bangis Kabupaten Pasaman Barat adalah sebagian besar responden memiliki pola asuh yang baik memiliki balita tidak stunting $37,5 \%$, sebagian besar responden yang memanfaatkan Posyandu memiliki balita tidak stunting yaitu $36,5 \%$ dan sebagian besar responden dengan sanitasi lingkungan yang tidak baik dengan balita stunting $23 \%$.

\section{Ucapan terima kasih}

Pada kesempatan ini perkenankan penulis mengucapkan terima kasih sebesar besarnya kepada Kemenristek DIKTI yang telah memberikan support berupa pendanaan melalui hibah dosen pemula sehingga penelitian ini dapat terlaksana dengan baik, Bupati Kabupaten Pasaman Barat, Dinas Kesehatan Kabupaten Pasaman Barat, Rektor Universitas Muhammadiyah Sumatera Barat, Ketua LPPM Universitas Muhammadiyah Sumatera Barat, Kepala Puskesmas Air Bangis, sebagai tempat penelitian, Bidan, kader dan tim yang telah membantu dalam penelitian ini. 


\section{Daftar Pustaka}

Atikah, Laily K. 2014. Risiko Pendidikan Ibu terhadap Kejadian Stunting Pada Anak 6-23 Bulan. JurnalPenel Gizi Makan Vol. 37. Desember 2014

Adiyanti. M. 2014. Pola Asuh Gizi, Sanitasi Lingkungan, Pemanfaatan Posyandu dengan Kejadian Stunting Pada Baduta di Indonesia (Analisis Data Riskesdas Tahun 2010). Fakultas Kesehatan Masyarakat. Universitas Indonesia. Nadiah, dkk. Faktor Risiko Stunting pada Anak Usia 0-23 Bulan di Provinsi Bali, Jawa Barat dan Nusa Tenggara Timur. Jurnal Glzi dan Pangan. Vol, No 2. Juli 2014

Dewi M, Mimin A. 2016. Pengaruh Edukasi Gizi terhadap Feeding Practice Ibu Balita Stunting Usia 6-24 Bulan. Indonesia Journal of Human Nutrition. Supl 18, Vol 3. No 1. Juni 2016

Departemen Kesehatan. 2014. Profil Dinas Dasar Indonesia Tahun 2013. Jakarta

KEMENKES RI. 2016. Pusat Data dan Informasi Kementerian Kesehatan Republik Indonesia. Jakarta : Kemenkes RI
KEMENKO PMK RI. 2018. 160 Kabupaten/Kota dengan Prioritas Masing-Masing 10 Desa Untuk Penanganan Stunting. Jakarta

Notoatmodjo, Soekidjo. 2012. Metodologi Penelitian Kesehatan. Jakarta: PT Rineka Cipta, 2012.

Okky FA, dkk. 2015. Faktor-faktor yang Mempengaruhi Kejadian Stunting pada Anak Balita di Wilayah Pedesaan dan Perkotaan. E-Jurnal Pusataka Kesehatan, Vol 3 (No.1). Januari 2015.

Profil Dinas Kesehatan Kabupaten Pasaman Barat. 2016

RISKESDAS. 2013. Laporan Hasil Riset Kesehatan Bappenas dan Unicef. Buletin I Periode Emas Pada 1000 Hari Pertama Kehidupan. Bappenas. Jakarta.

Unicef Indonesia. 2016. Ringkasan Kajian Air Bersih, Sanitasi, dan Kebersihan. Diakses di www.unicef.go.id

World Health Organization. 2017. Childhood Stunting: Challenges and opportunities. Report of a Promoting Healthy Growth and Preventing Childhood Colloquium. Geneva

World Health Organization. 2008. Training Course on Child Growth Assessment 